\title{
ANALISIS PENGGUNAAN SKEMATA DALAM BAHASA IKLAN ANAK
}

\section{An Analysis of Schemata Usage in Children Discourse Advertisement}

\author{
Hyunisa Rahmanadia \\ Universitas Indonesia
}

\begin{abstract}
Abstrak
Penelitian mengenai iklan sudah banyak dilakukan untuk menemukan cara pengemasan iklan yang ideal. Namun, penelitian tersebut masih belum dapat menjelaskan bagaimana iklan tersebut berpengaruh terhadap pikiran pembacanya. Dengan menggunakan teori skemata yang berhubungan dengan struktur kognitif dalam pikiran seseorang dan teori perkembangan anak dari Hurlock, penelitian ini membahas mengenai penggunaan bahasa dengan memanfaatkan skemata dalam pembuatan iklan anak. Iklan yang efektif dan efisien akan dapat memancing pengalaman yang dimiliki oleh seorang ketika membaca iklan tersebut sehingga anak itu akan lebih mudah mengingat pesan yang disampaikan. Objek penelitian ini adalah iklan untuk anak-anak yang termuat dalam majalah anak-anak "Bobo" dari bulan Januari sampai Agustus 2012. Hasil penelitian ini menunjukkan bagaimana penempatan informasi baru dalam skemata anak yang dapat digunakan untuk membantu para pembuat iklan dalam mengemas iklan.
\end{abstract}

Kata kunci: teori skema, bahasa iklan , iklan anak.

\begin{abstract}
There are a lot of researches on advertisement, but most of them doesn't explain how ads influencing the cognitive structure of the reader. Using schemata theory and growth development theory by Hurlock, this research could explain the way how language evokes the schemata that the readers of ads has. The effective ads will be able to recall the schemata, so it can be easily memorize and retrieve by stimuli. The data of this research was collected from 'Bobo' Magazine from January to August 2012. The result of this research indicate how new information is placed on schemata of the ads reader. This result can help copywriters to make the effective ads.
\end{abstract}

Keywords: schemata theory, language of advertisements, children ads. 


\section{PENDAHULUAN}

Media merupakan sarana komunikasi yang berguna untuk menghubungkan pemikiran seseorang atau sekelompok orang kepada orang lain atau kelompok lain. Sudah banyak kajian yang membahas mengenai media dari ranah kajian wacana, gramatikal, sosiolinguistik, filsafat maupun psikologi. Hal ini dikarenakan peran media yang sangat berdampak besar dalam membentuk pemikiran masyarakat dengan paparannya yang terus-menerus. Kajian media yang membahas mengenai hubungan media dengan masyarakat sebagai targetnya pada akhirnya akan berujung dengan bahasan munculnya hegemoni dalam masyarakat tersebut. Media dianggap dapat memengaruhi dan bahkan mengubah pemikiran atau cara pandang hidup suatu masyarakat. Dari kesadaran inilah, media mulai dianggap penting dan kajian mengenai hubungan media dan masyarakat pun terus mengalir.

Salah satu isi media yang paling sering muncul di kehidupan kita adalah iklan. Hal ini dikarenakan pada era globalisasi, iklan memiliki fungsi strategis dalam berbagai bidang. Banyak penelitian yang telah dilakukan membahas mengenai iklan. Namun penelitian untuk mencari formula iklan yang ideal belum sampai pada tataran kognisi seseorang. Padahal menurut Gentry, iklan yang efektif adalah iklan yang menarik, mudah dicerna dan berhubungan dengan struktur kognisi target iklannya.

For advertising to be effective, the receiver must (1) notice it, (2) process its content, and (3) favorably relate that content to his/her cognitive structure.

(Gentry,1984)

Berdasarkan pendapat tersebut, Penelituan ini berusaha untuk menjelaskan struktur kognitif dalam pikiran setiap pembaca iklan yang berperan penting membuat pembaca dengan mudah akan mengingat iklan suatu produk. Untuk mengetahui struktur kognitif ini, teori yang dapat digunakan adalah teori skemata.

Teori schema atau schemata digunakan pertama kali oleh Immanuel Kant lalu dikembangkan oleh berbagai ahli seperti Guy Cook (1994) dan Elena Semino (1997). "A scheme is a systematic organization of cognitive experience and action" (David, 1978 : 152). Shimizu (seperti yang dikutip oleh Orestis Soidi (2007)) mengungkapkan bahwa skema atau skemata adalah struktur sistematis dari kumpulan berbagai pengetahuan yang diperoleh sejak masa kanak-kanak. Dengan demikian, pengetahuan atau skema yang dimiliki oleh setiap orang pasti akan berbeda-beda mengingat tak ada satu orang pun yang memiliki latar belakang, jalur kehidupan dan pikiran yang sama.

Dalam penelitian ini, jenis iklan yang diteliti adalah jenis iklan yang bersifat komersil, yaitu berfungsi untuk mempromosikan suatu produk atau jasa kepada pembacanya. Target atau sasaran suatu iklan bergantung pada produk yang ditawarkan. Tidak hanya para pemuda dan orang dewasa, anak-anak dan orang-orang tua pun menjadi target suatu iklan. Mengingat usia anak-anak lah (terutama 5-9 tahun) yang menduduki peringkat tertinggi pada sensus penduduk 2010 yang dilakukan oleh Badan Pusat Statistik Indonesia yaitu mencapai 23.253.480 jiwa (http://dds.bps.go.id/booklet/Booklet_Feb_2012.pdf), penulis kemudian memilih iklan anak-anak sebagai objek penelitian.

Iklan memiliki banyak cara atau strategi dalam membujuk dan menarik minat para target iklannya. Salah satu caranya adalah menggunakan atau memunculkan image schemata yang baik terhadap produk yang ditawarkan dalam iklan yang bersangkutan. Pengertian mengenai image schemata itu sendiri dapat terlihat pada penjelasan di bawah ini: 
Image schemas are abstract representations of recurring dynamic patterns of bodily interactions that structure the way we understand the world. They are schematic and exist beneath conscious awareness.

(Sacristan dan Cortes de la Rios ;2009)

Image schemata adalah salah satu cara yang sangat berpengaruh dalam membujuk pembaca, pendengar atau target iklan untuk membeli produk atau jasa yang ditawarkan. Dengan memberikan gambaran yang menyenangkan dari suatu pengalaman yang dihubungan dengan produk tertentu, target iklan akan tertarik dan membeli produk nyata dari iklan tersebut (Meyers Levy dan Malaviya (1999) dalam Sacristan dan Cortes de la Rios (2009)). Iklan-iklan tersebut memunculkan image schemata dengan berbagai cara seperti menggunakan metafora.

Tujuan dari penelitian ini adalah untuk mengetahui bagaimana struktur yang digunakan suatu iklan dalam menyampaikan pesannya kepada anak-anak. Dengan analisis menggunakan teori skema yang berhubungan dengan pengetahuan yang tersimpan dalam ingatan setiap anak, kita akan dapat mengetahui bagaimana iklan dapat menarik perhatian anak. Kemudian berdasarkan teori skema kita akan dapat mengetahui proses menempatan informasi dalam skema apa sajakah yang digunakan oleh pembuat iklan anak dalam majalah "Bobo", untuk menarik minat para pembaca (anak-anak) agar membeli produk yang sedang diiklankan.

\section{Metodologi}

Jenis penelitian ini adalah penelitian kualitatif. Data yang dikumpulkan berasal dari majalah "Bobo" pada awal tahun 2012. Majalah ini dipilih sebagai salah satu majalah yang baik mewakili majalah anak-anak di Indonesia karena majalah ini merupakan salah satu majalah yang telah memiliki reputasi baik dan tersebar di hampir seluruh pelosok Indonesia. Data yang berhasil dikumpulkan sejumlah 59 iklan yang termuat dari majalah "Bobo" yang terbit dari bulan Januari sampai Agustus karena telah dapat menampilkan keberagaman iklan yang komprehensif. Iklan tersebut akan dianalisis dengan menggunakan teori skema yang dikemukakan oleh Piaget. Paget mengelompokkannya proses perkembangan menjadi dua kelompok yaitu assimilasi dan akomodasi (Piaget, 1988:62). Kedua proses tersebut disebut oleh Piaget sebagai 'fungsi-fungsi invariant). Teori perkembangan anak yang dikemukakan oleh Hurlock juga akan digunakan untuk mendukung analisis skema yang digunakan.

\section{Hasil dan Pembahasan}

Pembahasan selanjutnya memaparkan mengenai struktur skema pada berbagai jenis tipe iklan. Berbagai tipe iklan dibuat menggunakan suatu struktur skema untuk mencapai tujuannya. Dari analisis inilah akan diketahui kecenderungan suatu tipe iklan untuk memanfaatkan suatu struktur skema.

Setelah analisis dilakukan terhadap 59 iklan, penulis menemukan ada 3 tipe iklan yang digunakan untuk menarik perhatian mereka. Skema tersebut adalah 'hadiah', 'idola', dan' permainan'. Setiap iklan terkadang dapat mengaktifkan lebih dari satu tipe iklan untuk lebih menarik perhatian anak dan lebih mudah diingat. 


\section{Tipe Iklan Ber 'hadiah' dengan Assimilasi}

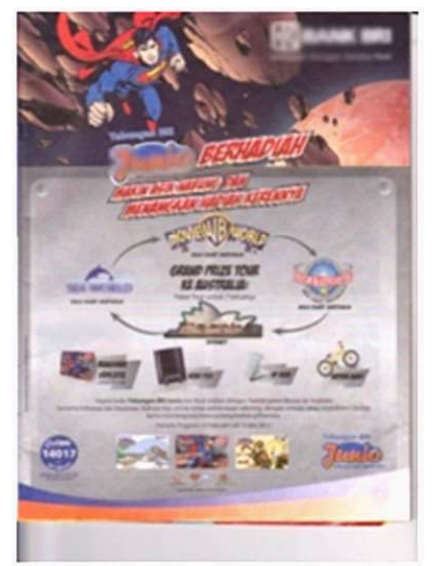

Skema 'hadiah' yang ada dalam pikiran anak-anak banyak digunakan oleh para pembuat iklan mengingat anak-anak akan sangat senang jika mendapat hadiah dalam bentuk apapun. Teori reinforcement pada analisis psikologis dalam pembelajaran menjelaskan bahwa tingkah laku manusia yang selalu mengarah pada tujuan atau hasil akan membuat mereka bertindak untuk melakukan suatu aksi atau yang kemudian disebut sebagai pembelajaran. Hadiah dan hukuman merupakan suatu cara untuk membangkitkan semangat anak dalam belajar (David, 1978: 249).

Selain itu, berdasarkan "the three A's of happiness" Hurlock menjelaskan bahwa ada 3 hal yang membuat anak-

anak bahagia yaitu penghargaan (achievement), penerimaan (acceptance), dan kasih sayang (affection) (Hurlock,1994:153). Seorang anak akan merasa bangga dan senang jika berhasil menyelesaikan sesuatu meskipun suatu hal yang tampak sepele sekalipun. Penghargaan akan membantu mereka menyadari keberhasilan itu dan juga menunjukkan bahwa dirinya diterima oleh orang lain yang merupakan poin kebahagian yang kedua. Seringnya anak mendapat hadiah atau penghargaan akan membuat mereka memiliki kesan yang baik pada konsep 'hadiah'. Sehingga pada umumnya mereka akan tertarik mendengar atau membaca kata 'hadiah'.

Contoh tipe iklan ber'hadiah' dapat dilihat pada gambar 1. Pada gambar tersebut kata "berhadiah" sengaja dicetak dengan ukuran yang lebih besar untuk menarik minat anak. Dengan kata kunci tersebut, iklan tersebut akan memancing anak untuk memasukkan jenis produknya dalam skema 'hadiah' yang sudah ada dalam pengetahuan mereka. Dalam hal ini maka assimilasi akan terjadi pada skema yang sudah dimiliki seorang anak.

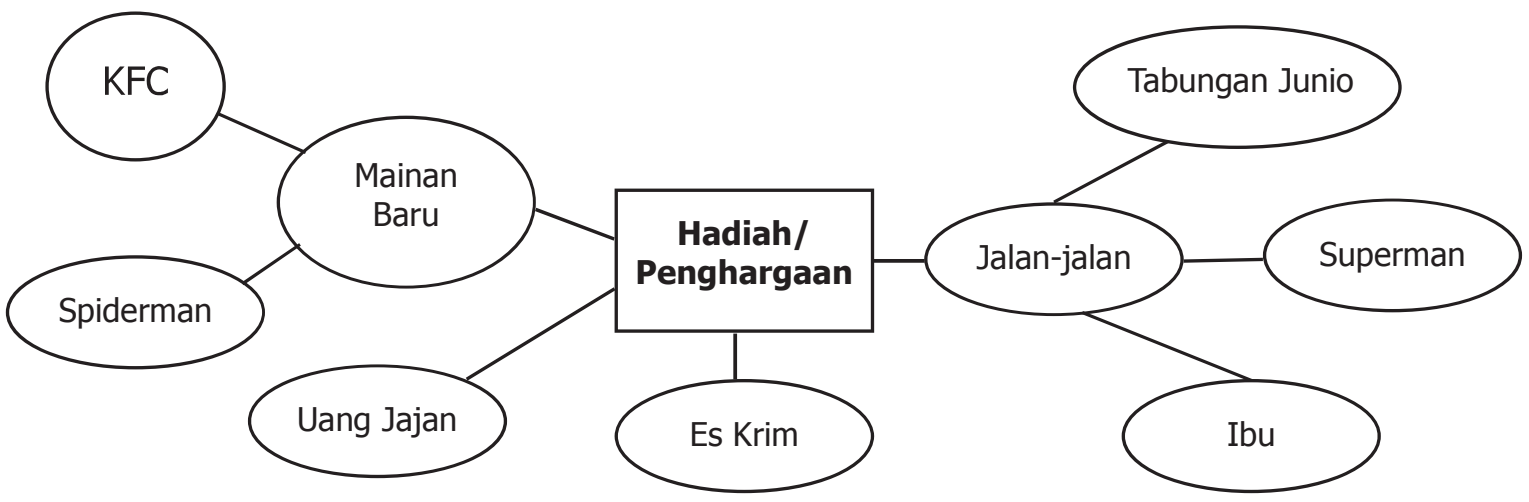

Bagan 1. Struktur skema pada konsep hadiah yang terbentuk dari iklan ber 'hadiah'

Kemampuan setiap anak dalam mengolah informasi baru berbeda-beda. Dalam assimilasi, anak akan menggabungkan informasi baru ke dalam konsep yang sudah ada secara general. Misalnya, seorang anak yang telah memiliki konsep mengenai mobil, akan memasukkan 'bus' ke dalam konsep 'mobil'. Hal ini dikarenakan 'bus' dan 'mobil' memiliki ciri-ciri yang sama, seperti memiliki roda, pintu, jendela, setir, dan kesamaan lainnya. 
Pada bagan di atas, seorang anak akan diarahkan oleh iklan pada gambar 1 untuk memasukkan 'tabungan junio' ke dalam konsep hadiah melalui 'jalan-jalan' sebagai hadiahnya. Oleh karena itu jika suatu saat dia mengingat mengenai konsep 'hadiah', ingatan anak tersebut akan terarah pada 'jalan-jalan' lalu menabung di 'tabungan junio' untuk mendapatkannya.

Pada struktur skema di atas, konsep ibu juga muncul ketika seorang anak membaca iklan tersebut. Hal ini dikarenakan orang tua, baik itu ibu maupun ayah yang akan membantu mereka mendapatkan hadiah dengan membuka tabungan di bank yang bersangkutan. Pada struktur skema anak yang lain bisa saja konsep ayah yang mucul untuk membantu mereka.

\section{Tipe Iklan Menggunakan Konsep 'Idola' dengan Assimilasi}

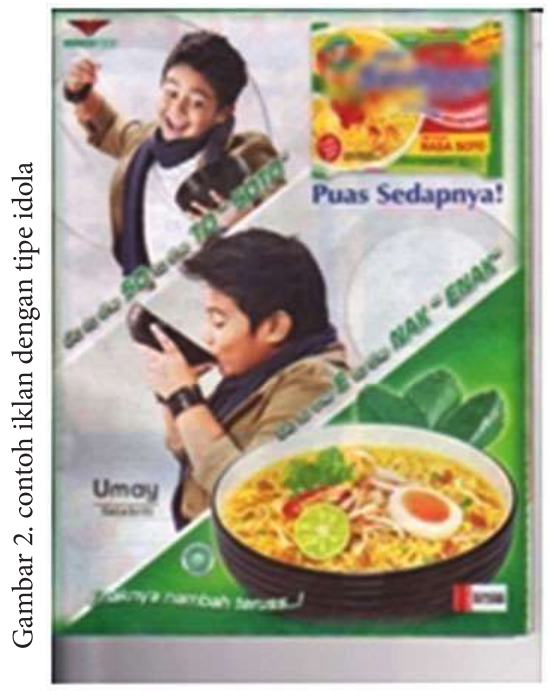

"Parents and agents of socialization provide important models or patterns for children to emulate. The child is urged, directly and indirectly, by several kinds of pressure to adopt the same kind of behavior displayed by parents, teachers, and other adults".

(David,1978:246)

Pernyataan tersebut menunjukkan bahwa dalam proses pembelajaran, anak akan memiliki kecenderungan untuk meniru sebuah figur atau tokoh idola yang dekat dengannya. Bentuk pembelajaran seperti ini tidak hanya dapat membentuk perangai yang kompleks, namun juga tingkah laku, nilai-nilai dan kepercayaan (Bandura dan Walters,1963 dalam David, 1978:246). Orang tua memiliki peranan yang paling besar sebagai agen sosialisasi dalam dunia anak. Selain orang tua, guru, orang lain di luar rumah, teman dan ketika bertambahnya usia, anak yang lebih tua pun dapat menjadi idola mereka.

Saat ini media masa telah menjadi agen sosialisasi yang memiliki kekuatan yang sangat besar. Hal ini dikarenakan media masa banyak digunakan sebagai alat untuk mengalihkan perhatian anak. Sering kita temukan anak yang diam berlama-lama di depan televisi sehingga tidak mengganggu kegiatan orang tua mereka atau karena alasan yang lain. Bahkan di Amerika, media masa kini sudah menjadi lebih dari sekedar hiburan. Media masa telah menjadi agen sosialsasi yang membentuk perkembangan anak (David,1978:247).

Contoh iklan pada gambar 2 menunjukkan pemanfatan proses belajar anak dengan imitasi dalam menarik minat anak untuk membaca dan membeli produk yang ditawarkan. Tokoh idola anak 'Umay' yang merupakan penyanyi cilik yang memenangkan kompetisi menyanyi dalam sebuah stasiun televisi dimunculkan untuk memanggil kembali skema idola yang ada dalam fikiran anak. Ketenaran tokoh idola ini diperkuat dengan memunculkan tulisan "Umay-Selebriti".

Dalam peran pembelajaran pada emosi anak yang disebutkan oleh Hurlock, pembelajaran dengan menirukan (imitate) berpengaruh terhadap emosi dan tanggapan yang terjadi pada anak (Hurlock, 1978: 210). Seorang anak akan merasa takut terhadap ular jika dia melihat orang-orang yang ada disekitarnya juga lari ketika berhadapan dengan ular. Berdasarkan teori tersebut, contoh iklan pada gambar 2 menarik minat anak untuk membeli produknya dengan menampilkan seorang tokoh idola yang tampak menyukai produk yang ditawarkan. Iklan tersebut diharapkan dapat memicu aksi anak untuk menirukan tokoh idolanya kemudian membeli produk tersebut. 
Struktur skema yang dapat terbentuk pada seorang anak setelah melihat iklan tersebut terlihat pada bagan dibawah ini:

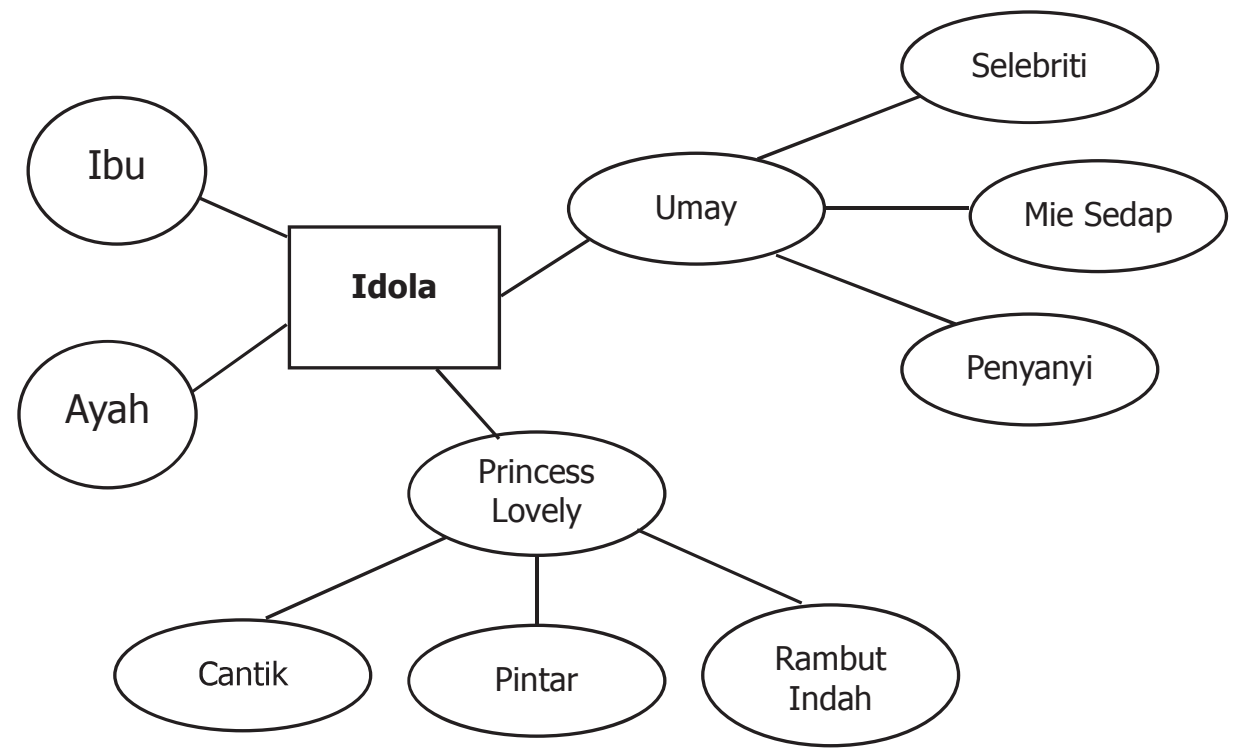

Bagan 2. Struktur skema tokoh idola yang terbentuk dari iklan dengan konsep idola

Struktur skema di atas menunjukkan bahwa dengan membaca iklan tersebut, seorang anak akan mengaitkan produk yang ditawarkan oleh iklan tersebut dengan idola mereka 'Umay'. Oleh karena itu jika suatu saat anak itu akan membeli mie, dia akan memanggil kembali skema yang sudah terbentuk mengenai idolanya 'Umay' yang menyukai produk tersebut, sehingga berdasarkan teori yang telah dipaparkan akan timbul keinginan untuk meniru tokoh idolanya. Jika saja anak tersebut tidak memasukkan 'Umay' ke dalam skema idolanya, maka iklan tersebut membantu mengenalkan kepada anak tersebut bahwa 'Umay' adalah seorang tokoh yang patut dijadikan idola dengan menambahkan kata 'selebriti' di bawah nama 'Umay'.

\section{Tipe Iklan Menggunakan Konsep 'Idola' dengan Akomodasi}

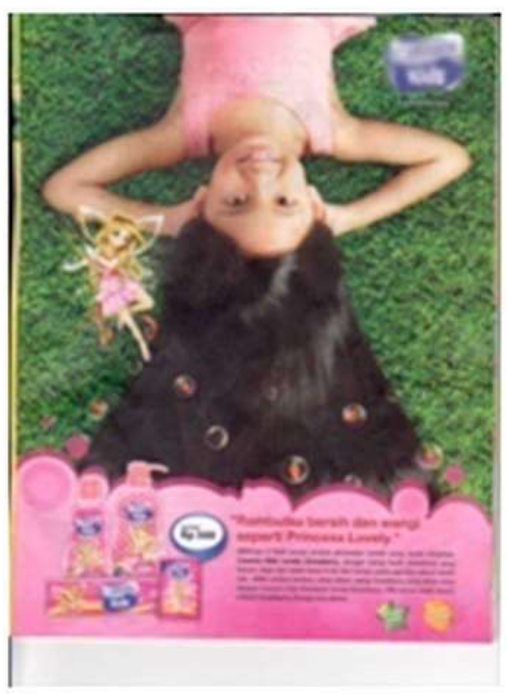

Gambar 3. iklan dengan konsep idola khayalan
Iklan di samping juga merupakan sebuah iklan yang menggunakan konsep idola dalam menarik perhatian anak. Berbeda dengan iklan dengan konsep idola sebelumnya, iklan ini membentuk tokoh idola khayalan dengan stimuli iklan-iklan sebelumnya yang ditampilkan dalam bentuk cerita bergambar. Cerita bergambar juga sangat menarik minat anak karena hal ini juga merupakan sebuah permainan dalam bentuk pasif atau hiburan (amusements). Hurlock juga memaparkan bahwa tema peri (fairy tales) juga merupakan suatu tema yang dapat menarik minat anak (Hurlock, 1994: 273). Seperti tampak pada gambar 4. Pada cerita seri bergambar yang menceritakan mengenai tokoh idola dalam bentuk peri, iklan itu memasukkan segala konsep kebaikan seperti terlihat pada bagan 2 pada tokoh idola ciptaan iklan tersebut. 


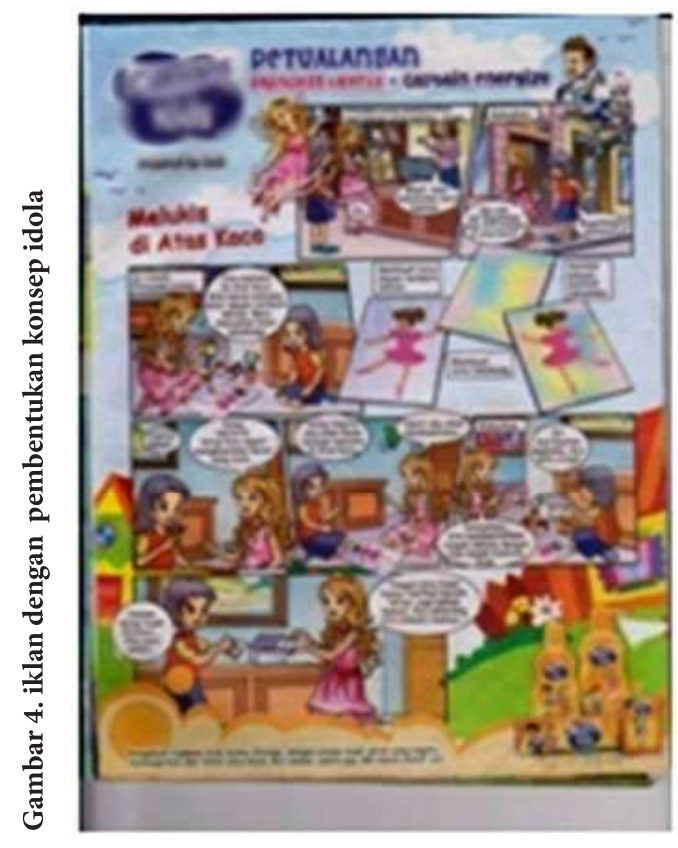

Dari konsep kebaikan yang dimasukkan ke dalam skema anak, iklan ini memunculkan image schemata bahwa dengan menggunakan produk ini, seorang anak akan memiliki rambut seindah Princess Lovely.

Pada bagan 2 juga terlihat bahwa proses assimilasi terjadi. Namun assimilasi ini terjadi pada anak di bawah umur lima tahun. Menurut Hurlock, ketika seorang anak mulai menginjak umur lima tahun seorang anak akan dapat membedakan manakah hal yang merupakan imajinasi atau khayalan dengan hal nyata (Hurlock,1994:197). Oleh karena itu, setelah umur lima tahun proses akomodasi pun terjadi. Kemudian, anak akan memasukkan tokoh idola khayalan tersebut pada konsep skema yang baru. Kemudian struktur skema yang terbentuk akan tampak seperti di bawah ini:

Bagan 3. Struktur skema Akomodasi dari Iklan dengan Konsep Idola

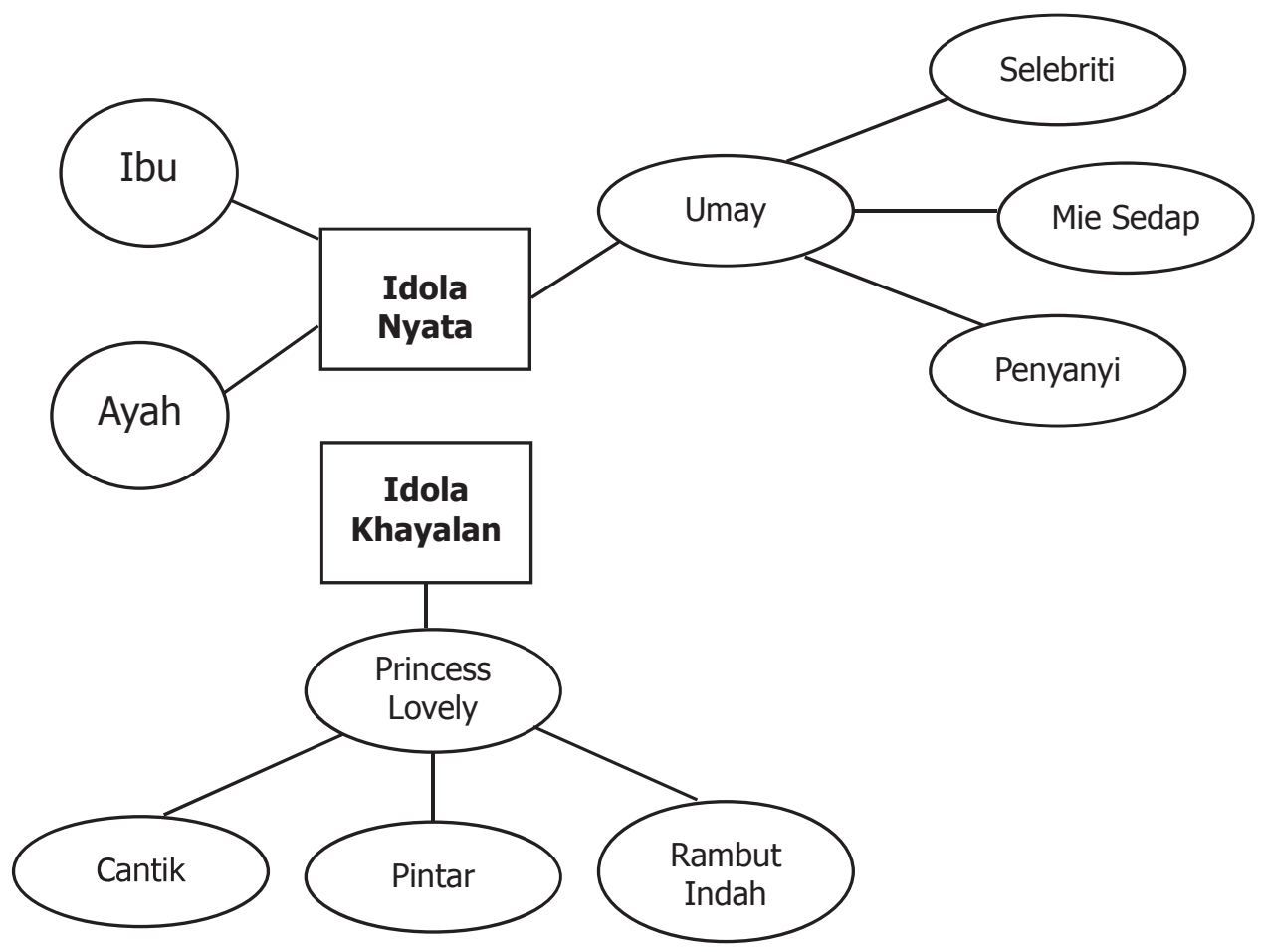

Dalam bagan di atas tampak bahwa seorang anak telah dapat memisahkan antara idola dalam dua tipe yaitu idola yang ada dalam kehidupan nyata dan idola yang hanya ada dalam dunia imajinasi. Media masa telah banyak menciptakan tokoh imajinasi ini dan menggunakannya dalam berbagai kepentingan. Dalam iklan yang lain digunakan tokoh seperti Spyderman, Superman, Tweety', 'Mickey Mouse', 'Donald Duck', sampai 'Tom and Gerry'. 


\section{Tipe Iklan Menggunakan Konsep 'Permainan" dengan Assimilasi}

Tipe iklan selanjutnya juga berhubungan dengan minat anak-anak dalam dunia permainan. Permainan selalu memberikan rasa senang pada seseorang. Bahkan Hurlock mendefinisikan permainan 'play' sebagai suatu aktivitas yang dilakukan untuk kesenangan yang dirasakan (Hurlock, 1994:265). Bagi anak, bermain tidak hanya merupakan suatu kegiatan yang membuang waktu. Banyak kebaikan yang didapat ketika seorang melakukan suatu permainan bagi perkembangan anak itu sendiri. Hurlock mengelompokkan jenis permainan menjadi dua kelompok yaitu permainan aktif dan hiburan (permainan pasif). Dalam permainan aktif, anak- anak akan merasakan kepuasan karena melakukan suatu sendiri suatu kegiatan. Dalam permainan aktif, Hurlock mengelompokkan jenisnya menjadi exploratory play, construction, dramatic play, family games, dan neighborhood games (Hurlock, 1994:269-272).

Contoh iklan di bawah ini adalah iklan yang menggunakan konsep permainan dengan jenis exploratory games dalam skema mereka untuk menarik minat anak. Hal pertama yang menarik minat anak berumur di bawah tiga tahun adalah menjelajahi atau menyelidiki suatu mainan. Dia akan melempar, menggigit dan mencium mainan itu untuk memenuhi rasa keingintahuan mereka. Mainan baru akan selalu membuat mereka tertarik dan mengundang rasa penasaran mereka. Curiosity is things that are new and different may make children want to explore them (Hurlock,1994:211).

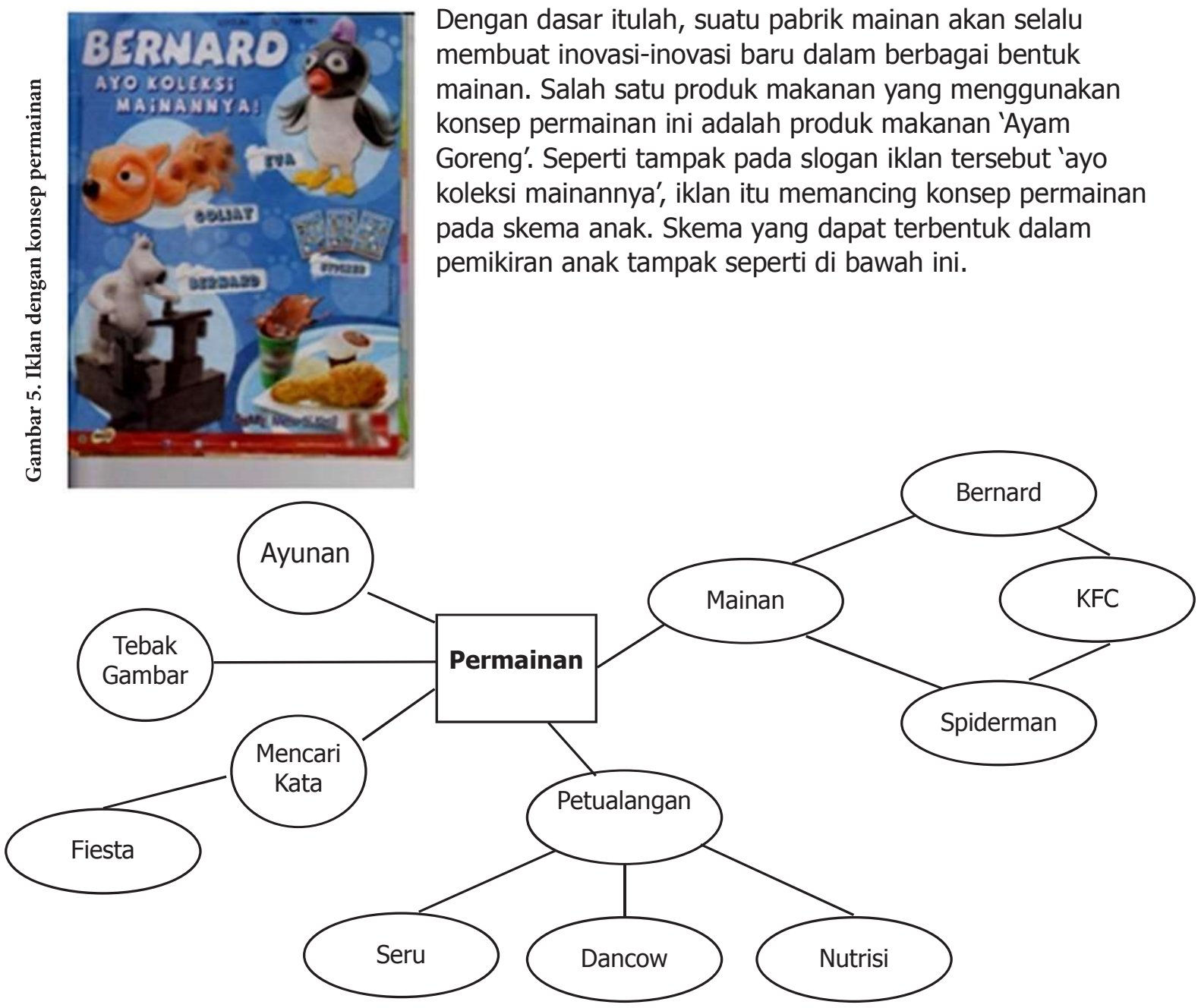

Bagan 4. Struktur skema dengan konsep 'Permainan' yang diasumsikan muncul setelah melihat beberapa iklan yang di analisis. 
Struktur skema di atas menunjukkan skema anak yang menambahkan informasi suatu mainan baru ke dalam konsep permainan yang dimilikinya. Mainan baru dengan bentuk tokoh 'Bernard' tersebut akan mengingatkan anak tentang produk makanan 'KFC' dimana anak dapat mendapatkan mainan tersebut.

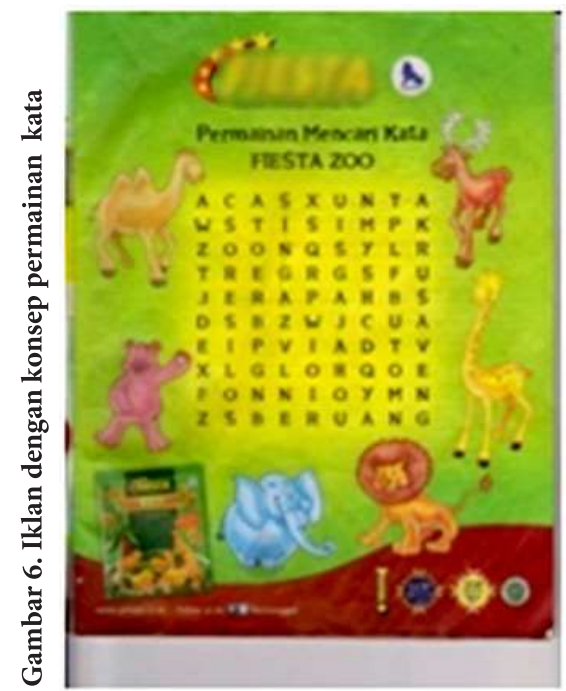

Ketika anak berumur lebih dari tiga tahun, anak mulai tertarik untuk membuat sesuatu dan bukan lagi pada tahap pengenalan terhadap suatu mainan. Tidak hanya untuk menjelajahinya, anak tertarik untuk menciptakan atau menyelesaikan sesuatu masalah (Hurlock,1994:270). Iklan berikut ini dikemas dalam bentuk permainan. Namun dengan bentuknya yang lebih menantang, iklan ini menimbulkan rasa penasaran anak dengan permainan mencari kata. Iklan ini akan sangat berpengaruh pada anak yang sedang belajar membaca. Iklan ini menggunakan proses asimilasi ke dalam skema anak karena iklan ini menambah informasi jenis permainan ke dalam skema mereka tentang konsep permainan. Hurlock mengelompokkan jenis iklan seperti ini ke dalam

family games yang dapat dimainkan di dalam rumah. Image schemata yang muncul dari iklan ini adalah produk 'Penganan siap saji' membuat anak menjadi cerdas dengan keragaman bentuk makanan yang menyerupai hewan sehingga anak akan dengan mudah mengingat nama-nama hewan tersebut.

Permainan yang membutuhkan gerak kinetis lebih besar misalnya adalah permainan dalam bentuk petualangan. Petualangan dapat dilakukan di dunia nyata seperti menjelajahi alam maupun dengan imajinasi anak dalam ruangan terbatas seperti bermain kemah-kemahan di rumah. Jika petualangan dilakukan dengan berimajinasi, Hurlock menamakan permainan ini sebagai dramatic play. Bagi para orang tua pun iklan dengan konsep permainan dengan berpetualang juga sangat menarik karena menurut Hurlock "Childern who are encouraged to be adventurous tend to be more creative than those who are always warned to be careful" (Hurlock,1994:200). Oleh karena itu orang tua yang menginginkan anaknya menjadi lebih kreatif akan memberikan perhatian lebih terhadap iklan tersebut.

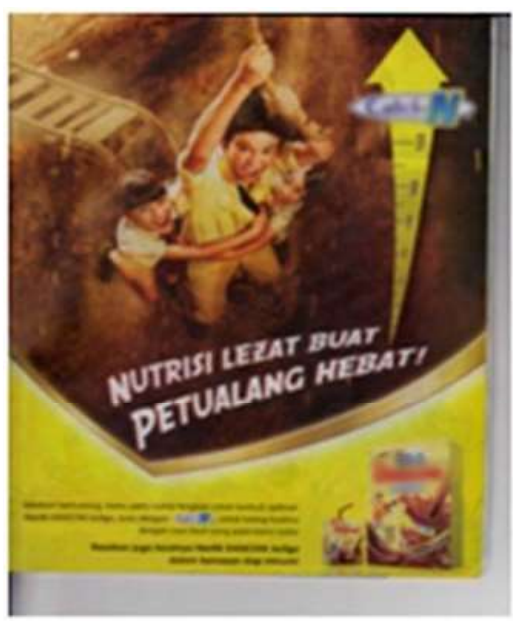

Konsep ini digunakan dengan efektif pada iklan produk 'susu'. Seperti tampak pada bagan 4, setelah membaca iklan ini anak akan menambah pengetahuan dalam skemanya menganai konsep permainan dengan informasi mengenai aktivitas berpetualang. Iklan ini menampilkan kata 'Petualang' dengan ukuran huruf yang paling besar agar mudah ditangkap penglihatan anak dan memanggil kembali skema mereka mengenai konsep petualangan. Ketertarikan anak pada iklan akan membuat mereka membaca informasi selanjutnya. Dalam informasi tersebut dipaparkan

Gambar 7. Iklan dengan konsep permainan berpetualang 
"Nutrisi lezat buat petualang hebat, Sebelum bertualang kamu perlu nutrisi lengkap untuk tumbuh optimal, susu dengan calci-N, untuk tulang kuatmu dengan rasa lezat yang pasti kamu suka"

Informasi mengenai nutrisi yang diperlukan untuk bertualang mengalami assimilasi ke dalam skema anak mengenai konsep bermain. Informasi selanjutnya yang melekat pada skema anak adalah prosuk susu sebagai sumber nutrisi tersebut. Iklan ini memberikan banyak informasi yang sangat mempengaruhi proses kognitif anak. Informasi yang dipaparkan oleh iklan tersebut juga memberi image schemata yang baik akan produk yang bersangkutan dengan secara langsung memaparkan bahwa produk inilah yang dapat menunjang aktivitas anak untuk berpetualang dengan segala kandungan nutrisinya.

\section{Simpulan}

Banyak cara yang digunakan untuk menarik minat anak. Berdasarkan teori perkembangan anak, iklan-iklan tersebut menggunakan konsep-konsep yang sudah ada dalam skema anak untuk memudahkan anak menangkap pesan dan melekatkannya pada skema tersebut. Dengan demikian, suatu pemicu kecil yang muncul akan mengarahkan struktur berpikir anak ke pada iklan suatu produk yang bersangkutan dan menyebabkan anak memiliki keinginan untuk membeli produk tersebut.

Penelitian ini menunjukkan bahwa konsep yang sering digunakan dalam iklan dan berpengaruh terhadap perkembangan kognitif anak dengan skema yang dimilikinya adalah konsep hadiah, idola dan permainan. Konsep-konsep tersebut sangat dekat dengan anak, mengingat pola berpikir mereka yang masih sederhana. Kata-kata dalam iklan yang menyentuh skema berpikir anak dari ketiga konsep tersebut berpeluang besar untuk dipahami dan melekat dalam pikiran anak. Proses penanaman informasi pada skema anak yang paling sering digunakan adalah asimilasi. Meskipun demikian, hal ini juga bergantung pada usia anak. Anak yang telah dapat membedakan hal yang nyata dan imajiner akan mengalami proses yang berbeda dan mengelompokkan informasi ke dalam konsep yang berbeda sehingga terjadi proses akomodasi.

Analisis pada penelitian ini masih pada lingkup wacana sehingga belum mencakup analisis terhadap daya afektif terhadap anak dari iklan yang disajikan. Oleh karena itu penelitian ini dapat digunakan sebagai dasar dalam penelitian lain yang ingin mengkaji mengenai daya afektivitas suatu iklan terhadap anak atau dampak positif maupun negatif yang dapat mempengaruhi karakter atau sifat anak. 


\section{Daftar Pustaka}

Cook, Guy.1989. Discourse. Oxford: Oxford University Press.

Cook, Guy. 2006. The Discourse of Advertising. New York: Routledge.

David, J.W.M dan S. Gray Garwood. 1978. Understanding Childern Promoting Human Growth. USA: DC. Heath and Company.

Dogaru Mihaela. "Schema refreshment / Reinforcement in Advertising". <http://www.escoala.ro/limbi-straine/schema_refreshment.html>. 15 Agustus 2012 pukul 16:32.

Engel, J.F., Royer D.B. dan Paul W.M. 1995. Consumer Behaviour (Eight Edition). USA : The Dryden Press.

Gentry, James W and Debra A Haley.1984. "Gender Schema Theory as a Predicator of Ad Recall", dalam Advances in Consumer Research, Volume 11, halaman 259-264. Oklahoma: Oklahoma State University.

George M. Zinkhan and Jae W. Hong .(1991). ,"Self Concept and Advertising Effectiveness: A Conceptual Model of Congruency Conspicuousness, and Response Mode", dalam Advances in Consumer Research, Volume 18, eds. Rebecca H. Holman and Michael R. Solomon: Association for Consumer Research, halaman 348-354. Oklahoma: Oklahoma State University.

Hurlock, E.B. 1994. Child Growth and Development (cetakan ke-13). India: Tata McGraw-Hill Publishing Company Limited.

Kovecses, Zoltan. 2010. Metaphore: A Practical Introduction. New York: Oxford University Press.

Mulyawan, I Wayan. "Struktur Wacana Iklan Media Cetak Kajian Struktur Van Dik". <http:// ejournal.unud.ac.id/abstrak/4 i wyn mulyawan edited-revision.pdf>. 15 Agustus 2012 pukul 16.15 .

Piaget, Jean. 1988. Antara Tindakan dan Pikiran. Drs. Agus Cremers SVD (peny). Jakarta: PT Gramedia.

Sacristan, Maria Sol Velasco dan Maria Enrique Cortes de la Rios.(2009). "Persuasive Nature of Image Schematic Devices in Advertising: Their Use for Introductory Sexisms" dalam Revista Alicantina de studios Ingleses 22. Halaman 239-270.

SIL International. 1995. "Schema Theory of Learning. <http://www. sil.org/Lingualinks/ Literacy/ImplementALiteracyProgram/Schema TheoryofLeaning.htm>. 15 Agustus 2012 pukul 15.30.

Soidi, Orestis.2007. "Teori Skema dan Aplikasinya dalam Pengajaran Bahasa Asing" dalam Interlingua Vol 1 (April).

"Piaget Theory". <http://psychology.about.com/od/piagetstheory/a/keyconcepts.htm>. 15 Agustus 2012 pukul 14.20 .

<http://dds.bps.go.id/booklet/Booklet_Feb_2012.pdf>. 20 September 2012 pukul 15.40. 